\title{
Validation of some disease-resistance molecular markers associated with multiple diseases in tomato for marker-assisted selection program
}

\author{
A.Y.M. Nevame ${ }^{\mathrm{a}, \mathrm{b}, *}, \mathrm{Lu} \mathrm{Xia}^{\mathrm{a}}$, Zhang Wenting ${ }^{\mathrm{a}}$, Chofong G. Nchongboh ${ }^{\mathrm{c}}$, Li Wenhu ${ }^{\mathrm{a}}$, \\ Muhammad M. Hasan $^{\text {d, Md. Amirul Alam }}{ }^{\mathrm{e}, *}$, Si Longting ${ }^{\mathrm{a}}$ \\ a Molecular Biology Laboratory of Jiangsu Green Port Modern Agriculture Development Company, \\ Suqian, Jiangsu 223800 China \\ b Shandong Kenyuan Modern Agriculture Development Co., Ltd., Lanling County Economic Development \\ Zone, Shandong 277731 China \\ c Catholic University, Institute of Buea, Buea, Cameroon \\ d Bangladesh Institute of Nuclear Agriculture, BAU Campus, Mymensingh 2202 Bangladesh \\ e Faculty of Sustainable Agriculture, Horticulture and Landscaping Program, Universiti Malaysia Sabah, \\ Sandakan Campus, 90509 Sandakan, Sabah, Malaysia
}

*Corresponding authors, e-mail: amen.nevame07@yahoo.fr, amirulalam@ums.edu.my

Received 10 Sep 2019

Accepted 4 Jan 2020

\begin{abstract}
Marker-assisted selection (MAS) is a tool that is widely applied in tomato resistance breeding. To determine the robustness of some molecular markers commonly used in MAS, extensive screening of 964 tomato lines was performed under a controlled experimental condition. Initially, the application of 36 molecular markers targeting 26 resistance genes (R genes) and 14 major diseases was evaluated. Here, we employed basic molecular biology and bioinformatics techniques for analysis where polymorphism, accuracy and clearness of amplicons constituted the selection criteria of markers. Upon initial analysis, 20 of these markers designated as efficient markers, among which 8 were considered gene-based markers and referred to as perfect markers were selected for detail evaluation. Information extrapolated from PCR result revealed $18 \mathrm{R}$ genes that control 12 diseases were grouped under efficient markers. On the other hand, grouping of breeding lines based on the number of $\mathrm{R}$ gene harbored comprehensively revealed $62 \%$ of the lines to be void of $\mathrm{R}$ gene, while $38 \%$ carry different types of $\mathrm{R}$ genes. This provides us with an avenue to better understand new sources of resistance in the breeding lines. Conclusively, these efficient markers and their limited PCR condition can be suggested as basis of a diagnostic kit for MAS applications against 12 major tomato diseases and the identified resistant breeding lines could be conserved in order to be propagated as different sources of resistance for the development of new resistant varieties. Therefore, in areas with high vulnerability to diseases, high efficiency combination of the relevant $\mathrm{R}$ genes and their pyramiding into commercial tomato varieties are proposed to be implemented as a pragmatic approach.
\end{abstract}

KEYWORDS: efficient markers, R genes, MAS, resistance sources, breeding lines, tomato

\section{INTRODUCTION}

Tomato (Solanum lycopersicum L.) is an economically important vegetable crop cultivated worldwide. Recordings from 2001-2016 showed that the world harvested area and the total production of tomato have recorded a dramatic increase of approximately $22.8 \%$ and $63.5 \%$, respectively. China on her part has contributed tremendously and has experienced an increase of $36.9 \%$ in cultivable tomato land and $134.6 \%$ in production which ranked her as the world's leading tomato producer (www.fao.org/statistics/en). However, it's astonishing that the world's leading producer was ranked between 40th and 54th in the world in terms of yield per hectare during same period. The yield per hectare has been attributed to several factors among which diseases caused by different pathogenic agents are considered to be the significant importance $[1,2]$. In general, more than 60 pathogens include bacteria, fungi, oomycetes, viruses, and nematodes are known to be challenging to global tomato production [3]. The most economic important diseases of tomato include 
tomato yellow leaf curl disease, tomato spotted wilt, tomato mosaic disease, fusarium wilt, late blight, leaf mold, root-knot disease, bacterial spot, bacterial speck, gray leaf spot, bacterial wilt, fusarium crown and root rot, powdery mildew and verticillium wilt. In recent years, a manifold progress has been made on breeding of resistant tomato cultivars against the most devastating pathogens including fungi (Cladosporium fulvum, Verticillium dahliae), bacteria (Ralstonia Solanacearum), viruses (Tomato yellow leaf curl virus and Tobacco mosaic virus), oomycetes (Phytophthora infestans), and nematodes (Meloidogyne incognita) [4]. In China, at least 10 diseases have reportedly induced significant tomato yield reduction [5]. Interestingly, 17 of the 35 different mapped pathogen resistance genes (R gene) have been cloned successfully [6]. Wild relatives' tomato species: S. pimpinellifolium, S. pennellii, S. habrochaites, S. peruvianum, and $S$. chilense constitute the main sources of resistance for $\mathrm{R}$ genes that have been introgressed into cultivated tomato $[7,8]$.

The releasing of public genomic databases of tomato has sprouted the development of various molecular markers for the identification of $\mathrm{R}$ genes simply through PCR-based techniques. These markers have been and are being used in MAS, markerassisted breeding (MAB), introgression and pyramiding of functional genes in tomato $[8,9]$. Assets in using molecular markers in tomato breeding program are numerous but not limited to: elimination of environment effect, time saving, gene pyramiding, high-efficiency transfer of gene, detection of trait with low heritability and testing for specific disease resistance under a quarantine restriction. Nevertheless, other studies have reported advantages and disadvantages, robustness and weaknesses of molecular markers application in MAS breeding programs. In either situation, DNA markers within the gene of interest are the ultimate due to no recombination occurrence between trait and marker [10]. In view to promote and improve disease-resistance in tomato, various markers were extensively and successfully deployed in breeding programs [11-13]. With strong focus on resistance breeding in tomato, resistance traits have become important characteristics in distinctness, uniformity and stability (DUS) testing for Plant Breeders Rights (PBR) applications. Hence, in DUS testing of candidate varieties, molecular markers have been suggested to complement the field assay or used as an alternative technology [11]. In the case of multi-resistance gene screening, marker technology, while being faster than the conventional method of selection, remains relatively complex due to the fact that different markers involved in MAS were developed in varied experiment conditions. So, concerns have been raised about the reproducibility and high accuracy of some markers, thus compelling plant scientists and breeders to evaluate the robustness of these markers through ring test or in different set of varieties [11]. In tomato resistance breeding program, there exists limited information about the validation of the various commonly used molecular markers under identical PCR condition. Here, MAS was conducted to validate robustness of these markers while simultaneously accessing their sources of resistance in tomato breeding lines. This study aims to (1) apprehend the most suitable molecular markers for MAS under appropriate and properly controlled PCR reaction conditions; (2) access resistance spectrum of each tomato breeding line; and (3) recommend new resistance sources for improvement of commercial varieties or gene pyramiding.

\section{MATERIALS AND METHODS}

\section{Plant materials and molecular markers}

In total, 964 tomato (S. lycopersicum L.) lines bearing different resistance genes, developed from commercial tomato hybrids of Green Port Company located at Suqian City in China, were used in this study. These commercial hybrids were purchased from different seed companies in China and were labeled according to the type and number of $\mathrm{R}$ genes incorporated. Markers incorporated in this work were collection from a pool of published research finding. The markers were related to $26 \mathrm{R}$ genes, which control fourteen diseases in tomato with some of the molecular markers being composed of the gene-linked and others gene-based markers for extensive marker assisted selection (MAS). The major tomato diseases evaluated are tomato yellow leaf curl disease, tomato spotted wilt, tomato mosaic disease, fusarium wilt, late blight, leaf mold, rootknot disease, bacterial spot, bacterial speck, gray leaf spot, bacterial wilt, fusarium crown and root rot, powdery mildew and verticillium wilt.

\section{DNA extraction and polymerase chain reaction}

Total DNA was extracted from the fresh leaves of 60-day old tomato breeding lines using NuClear Plant Genomic DNA Kit (CWO531M) protocol (CWBiotech, Beijing, China) following Adedze et al [14]. The extracted DNA was adjusted to a final con- 
centration of $50 \mathrm{ng} / \mu \mathrm{l}$. Two PCR reactions were deployed based on the intended nature of electrophoresis gel analysis (with 160 volts) of the PCR products. For PCR products to be analyzed by agarose gel electrophoresis $25 \mu \mathrm{l}$ of PCR reaction mixture containing $12.5 \mu 1$ 2xTaq MasterMix plus loading buffer (CWBiotech, Beijing, China), $1 \mu \mathrm{l}$ of each forward and reverse primer at $10 \mu \mathrm{M}, 1 \mu \mathrm{l}$ of DNA extract, and $9.5 \mu \mathrm{l}$ of nuclease free water was used. In the case of polyacrylamide gel analysis, $10 \mu 1$ PCR reaction mixture containing $1 \mu l$ of DNA extract, $3.4 \mu \mathrm{l}$ 2xTaq MasterMix without loading buffer (CWBiotech, Beijing, China), $0.8 \mu$ l of each forward and reverse primer at $10 \mu \mathrm{M}$, and $4 \mu \mathrm{l}$ of nuclease free water were put in a PCR tube. Amplification reaction conditions were as follows: initial denaturation at $94^{\circ} \mathrm{C}$ for $2 \mathrm{~min}, 35$ cycles of denaturation at $94^{\circ} \mathrm{C}$ for $30 \mathrm{~s}$, annealing at $55^{\circ} \mathrm{C}$ for $30 \mathrm{~s}$, and extension at $72^{\circ} \mathrm{C}$ for $30 \mathrm{~s}$ followed by $72^{\circ} \mathrm{C}$ for $2 \mathrm{~min}$. The PCR products generated from $25 \mu \mathrm{l}$ reaction mix were separated on $2 \%$ agarose gel in $0.5 \times$ TAE buffer, stained with ethidium bromide, while those obtained from $10 \mu \mathrm{l}$ reaction mix were analyzed on $8 \%$ polyacrylamide gel, stained with silver. Visualization of agarose and polyacrylamide gel was done under UV and white light, respectively.

\section{Primers designing and molecular screening}

A total of 36 (gene-linked and gene-based) molecular markers were deployed in this work (Table 1). Previously published DNA sequences were exploited for designing primer pairs of these markers and commercially synthesized by Hangzhou Shangyasai Biotechnology Co., Ltd. Company, China. These primers were diluted to a concentration of $10 \mu \mathrm{M}$ before use and PCR reactions were similar with minor difference according to the nature of gel analysis (agarose or polyacrylamide) required for PCR products. MAS was performed with each marker used for screening 964 lines.

\section{Cloning and sequencing}

Markers that produced clear band on agarose gel were considered efficient markers from which PCR products were cloned by ligation of their purified amplicons onto pMD19-T Simple Vector. Constructs (pMD19-T-PCR fragment) were commercially sequenced by Hangzhou Shangyasai Biotechnology Co. Ltd. Obtained sequences were aligned using DNAMAN 7 bioinformatics software.

\section{Data scoring and analysis}

Markers that produce clear bands and informative PCR products were designated as efficient markers and those that fall within the $\mathrm{R}$ genes were referred to as perfect markers. Markers which showed abnormal PCR products were discarded and were not included in the final analysis. All the perfect markers were inclusively accepted in the group of efficient markers but not the reverse case. Amplicon size and other characteristics of the efficient markers were investigated with reference to previously published data and DNA sequencing results. To distinguish the plant material in course of accessing their resistance spectrum, all selection lines were grouped according to the respective number of genes they carried.

\section{RESULTS}

\section{High-efficient markers for MAS in tomato against virus}

To optimize multi-resistance screening, DNA amplification ability of different $\mathrm{R}$ genes related markers were monitored under the same PCR condition. In case of tomato yellow leaf curl disease, 8 markers were involved in the screening of 5 resistance genes: Ty 1, Ty 2, Ty 3 , Ty 4 , and ty 5 , with Ty 1 and Ty 3 known to be allelic. Out of the 8 molecular markers, 6 of them including ACY, Ty1-3, P6-25, SCAR1, SCAR2, and P1-16 that targeted $3 \mathrm{R}$ genes produced clear bands from PCR products incorporating ACY and Ty1-3 as gene-based markers. Two of these markers, Cauty 4 and ty5, were not considered in further experiment (Fig. 1a). The marker Sw-5-2 found within $S w-5 b$ gene together with marker SCAR421 were used in targeting the strong $\mathrm{R}$ gene $S w-5 b$ for tomato spotted wilt virus. Little genomic information regarding SCAR421 was found, however, both markers yielded good PCR products (Fig. 1b). Unfortunately, DNA upon several cloning attempts of SCAR421 positive sequencing result was never attained from its construct, thus excluding it from the group of efficient markers. Resistance genes for tomato mosaic virus Tm1 and Tm22 were tracked using SCAR and SCN131000 markers, respectively. Based on PCR results, SCAR showed unreliability while PCR bands produced by SCN131000 were clear (Fig. 1c). After critical consideration from the PCR results, three gene-based markers (ACY, Ty1-3, and Sw-5-2) together with P6-25, SCAR1, SCAR2, P1-16 and SCN131000 were selected as efficient markers (Table 2). 
Table 1 Sequences and information collected from different sources for 36 molecular markers related to different tomato diseases.

\begin{tabular}{|c|c|c|c|c|c|c|}
\hline Disease & Gene & Marker & Type & Forward primer & Reverse primer & Ref. \\
\hline \multirow{4}{*}{$\begin{array}{l}\text { Tomato leaf } \\
\text { mold (f) }\end{array}$} & $C f-19$ & P7 & SCAR & AGTGCAGAAATGGGTTGTGTA & CCGGAGATCAAGCTCAACCA & [15] \\
\hline & $C f g$ & $8 \mathrm{~F} / 12 \mathrm{R}$ & SCAR & TGGGAATTTACCCGAAAGAA & CCCAATCATTCAGTGCGTTA & \\
\hline & Cfg & $8 \mathrm{~F} / 10 \mathrm{R}$ & SCAR & TGGGAATTTACCCGAAAGAA & TTTCCGATGTAAAAGAAGGCATA & [16] \\
\hline & $C f g$ & $10 \mathrm{~F} / 10 \mathrm{R}$ & SCAR & TGTGGTGGTGAAGATCAAGTGA & TTTCCGATGTAAAAGAAGGCATA & \\
\hline \multirow{2}{*}{$\begin{array}{l}\text { Tomato } \\
\text { spotted wilt (v) }\end{array}$} & $S w-5 b$ & Sw-5-2 & SCAR & AATTAGGTTCTTGAAGCCCATCT & TTCCGCATCAGCCAATAGTGT & [17] \\
\hline & $S w-5 b$ & SCAR421 & SCAR & GACTTGTTGCCATAGGTTCC & GCCCACCCCGAAGTTAATCC & [18] \\
\hline \multirow{2}{*}{$\begin{array}{l}\text { Powdery } \\
\text { mildew (f) }\end{array}$} & Ol-1 & SCAB01 & SCAR & GCTTCTAGATGCAGAAAGTTGGCG & CGCCCATTCCCGCATATACAG & [19] \\
\hline & $\mathrm{Ol}-1$ & SCAG11 & SCAR & TGGGATCACAGATTAACAAATGCG & ATGTGTGCGATGAGAAACGTGG & [19] \\
\hline \multirow{2}{*}{$\begin{array}{l}\text { Tomato } \\
\text { mosaic (v) }\end{array}$} & $\operatorname{Tm} 1$ & SCAR & SCAR & CCACTGTATGATTTCTGCTAGTGAA & GCAAGCTAAGGTTTACATATATGCC & \\
\hline & $\operatorname{Tm} 22$ & SCN131000 & CAPS & AGCGTCACTCCATACTTGGAATAA & AGCGTCACTCAAAATGTACCCAAA & [21] \\
\hline \multirow{4}{*}{$\begin{array}{l}\text { Bacterial } \\
\text { wilt (b) }\end{array}$} & Bwr-12 & SLM12-2 & SSR & АTCTCATTCAACGCACACCA & AACGGTGGAAACTATTGAAAGG & {$[22]$} \\
\hline & Bwr-12 & SLM12-10 & SSR & ACCGCCCTAGCCATAAAGAC & TGCGTCGAAAATAGTTGCAT & [22] \\
\hline & Bwr-6 & SLM6-17 & SSR & TCСТTCAАATCTCССАТСАА & ACGAGCAATTGCAAGGAAAA & [23] \\
\hline & $B w r-6$ & SLM6-138 & SSR & CCAGGCCACATAGAACTCAAG & ACAGGTCTCCATACGGCATC & [23] \\
\hline \multirow{2}{*}{$\begin{array}{l}\text { Verticillium } \\
\text { wilt (f) }\end{array}$} & Ve1 & SCAR & SCAR & CCATGAACAGATGTGACTTGTGTG & AAGTTTCTTATTTTTCСТTCTCC & {$[24]$} \\
\hline & Ve2 & SCAR & SCAR & CCATGAACAGATGTGACTTGT & SATTTTTGACGTGATA & \\
\hline \multirow{3}{*}{$\begin{array}{l}\text { Fusarium } \\
\text { wilt (f) }\end{array}$} & I1 & At2 & SCAR & CGAATCTGTATATTACATCCGTCGT & GGTGAATACCGATCATAGTCGAG & [11] \\
\hline & I2 & $\mathrm{I} 2 \mathrm{OH}$ & SCAR & TGGAGAGTTCCCTACAC & TTC & {$[25]$} \\
\hline & I3 & P7-43DF1 & SCAR & ATTTGAAAGCGTGGTATTGC & CTTAAACTCACCATTAAATC & [26] \\
\hline \multirow{3}{*}{$\begin{array}{l}\text { Root knot } \\
\text { nematode (n) }\end{array}$} & $M i-1.2$ & SCAR-1 & SCAR & TGGAAAAA & GCATACTATATGGCTTGTTT & [27] \\
\hline & Mi1-2 & Pmi3 & SCAR & GGTATGAGCATGCTTAA & CCTACAAGAAATTATTGTG & [28] \\
\hline & $M i-1$ & REX-1 & CAPS & TCGGAGCCTTGGTCTGAATI & GCCAGAGATGATTCGTGAG & \\
\hline $\begin{array}{l}\text { Bacterial } \\
\text { spot (b) }\end{array}$ & $\operatorname{Rex} 4$ & Pcc12 & Indel & TCCACATCAAATGCGTTTCT & TTCCAATCCTTTCCATTTCG & {$[30]$} \\
\hline $\begin{array}{l}\text { Bacterial } \\
\text { speck (b) }\end{array}$ & Pto & Pto & CAPS & ATCTACCCACAATGAGCATGAGCTC & GTGCATACTCCAGTTTCCAC & {$[31]$} \\
\hline $\begin{array}{l}\text { Fusarium } \\
\text { crown and } \\
\text { root rot (f) }\end{array}$ & Frl & SCARfrl & SCAR & CACATTCATCATCTGTTTTTAGTCTATTC & CACAATCGTTGGCCATTGAATGAAGAAC & {$[32]$} \\
\hline $\begin{array}{l}\text { Gray leaf } \\
\text { spot (f) }\end{array}$ & $S m$ & D5 & SCAR & CCCGTGGCACTACAACTCTT & TCTGCTTTCGCTCTGCTTGA & {$[33]$} \\
\hline \multirow{2}{*}{ Late blight (o) } & $P h 3$ & Ph3-2 & SCAR & TCATGCATTGTTTAGCCTGACA & ACTGCAAAGA & {$[34]$} \\
\hline & Ph3 & Ph3-3 & SCAR & ATGTCCCAGTTCCTCCAGGT & AGCAATTCCTAAACGTATTG & 5 \\
\hline \multirow{8}{*}{$\begin{array}{l}\text { Tomato } \\
\text { yellow leaf } \\
\text { curl virus (v) }\end{array}$} & Ty 1, Ty 3 & Тy1-3 & Indel & GGGTGATCCGTTGATTGAAG & TCTTCTTGATAGGACGACGTGA & [35] \\
\hline & Ty1,Ty3 & ACY & Indel & GAA GCA CAG ATTGAAGAAAACC & CCTTATGATGTCTCGTGA AAGG & [14] \\
\hline & Ty 2 & P1-16 & SCAR & CACACATATCCTCTATCCTATTAGCTG & CGGAGCTGAATTGTATAAACACG & \\
\hline & Ty3 & P6-25 & SCAR & GGTAGTGGAAATGATGCTGCTC & GCTCTGCCTATTGTCCCATATATAACC & {$[37]$} \\
\hline & Ty 2 & SCAR2 & SCAR & TGGCTCATCCTGAAGCTGATAGCGC & AGTGTACATCCTTGCCATTGA CT & \\
\hline & Ty1 & SCAR1 & SCAR & CAATTTATAGGTGTTTTTGGGACATC & GTTCAACACTTGGCCAATGCTTACG & 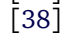 \\
\hline & Ty 4 & Cauty4 & Indel & GGGCAACTCAATGGTGAAAC & TCTGAATGTAGGGCCAAAGG & \\
\hline & ty 5 & ty-5 & SSR & GACTGCATTGGATTTGGCTT & CAATCGATGCACAAAACACC & \\
\hline
\end{tabular}

f, fungus; o, oomycete; b, bacteria; v, virus; $n$, nematode.

\section{Detected high-efficient markers for MAS in tomato against nematode and oomycete}

In order to screen for resistance against root knot nematode, Rex-1 and SCAR-1 markers that are linked to resistance genes $M i-1$ and $M i-1.2$, respectively, in addition to Pmi3 marker connected to Mi1-2 gene were used. On the basis of PCR outcome these three candidate markers generated clear and informative genetic bands as viewed on gel picture, thus considering them as efficient markers (Fig. 1d). Marker SCAR-1, successfully developed using coding sequence of $M i-1.2$ gene, was incorporated in efficient markers group. Oomycete resistance screening was based on tracking late blight resistance gene Ph3 of which two molecular markers Ph3-2 and Ph33 linked to this gene produced amplified diseaseresistance and susceptible alleles from the breeding lines employed in this research work (Fig. 1e). Comprehensively, markers Rex-1, SCAR-1, Pmi3, Ph3-2, and Ph3-3 were selected as efficient markers for root knot nematode and late blight resistance screening in tomato (Table 2). 

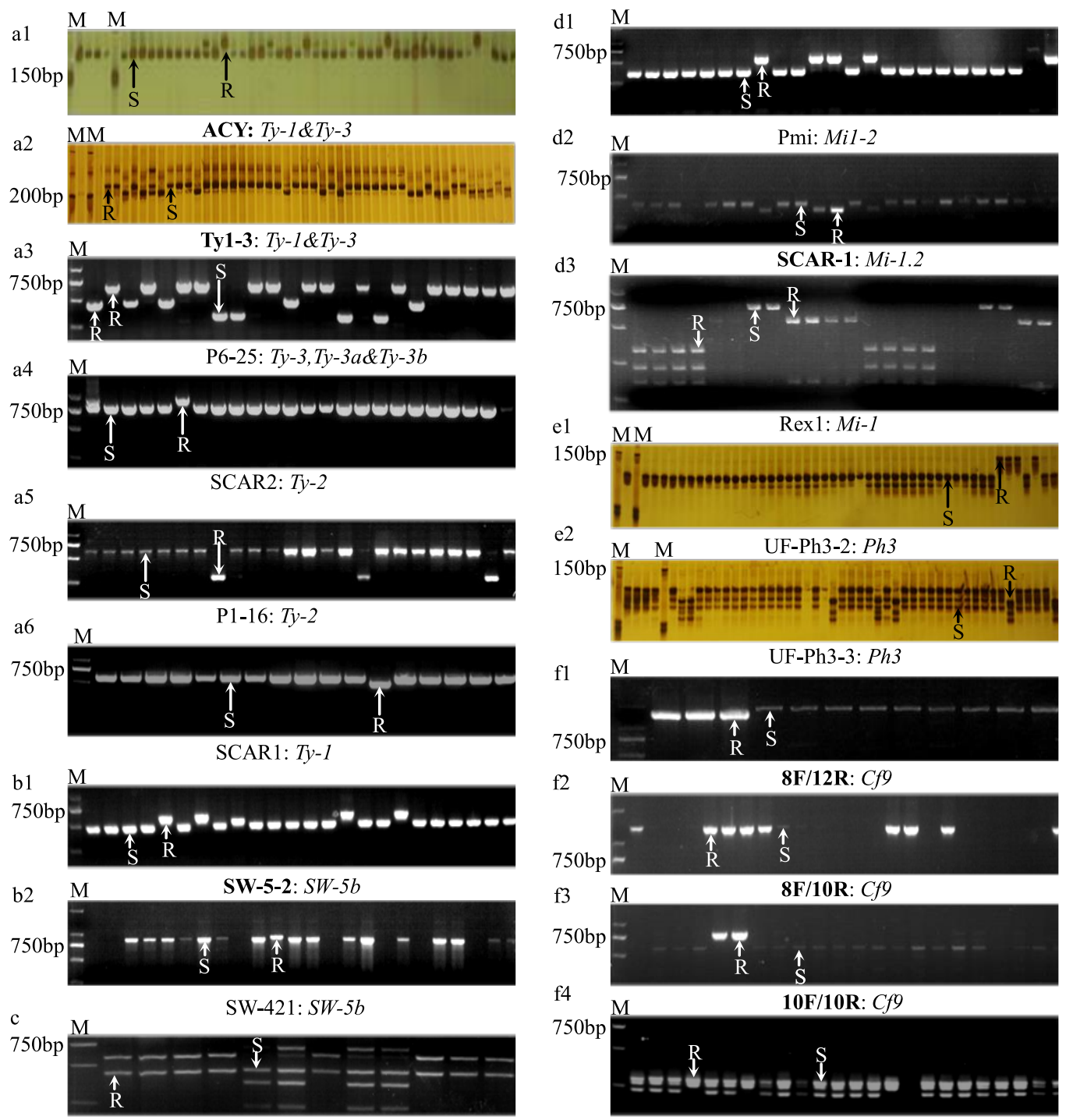

SCN131000:Tm22

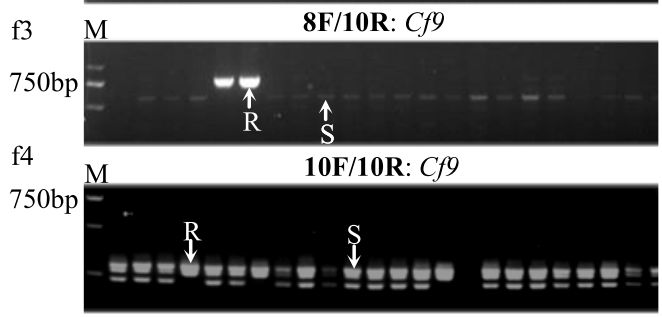

$\mathrm{P} 7: C f 19$

Fig. 1 Gel pictures of screened tomato breeding lines using molecular markers related to major disease resistance genes (R genes). (a1-6) Evaluation of resistance to tomato yellow leaf curl disease of ACY, Ty1-3, P6-25, SCAR2, P1-16, and SCAR1 markers; (b1-2) Sw-5-2 and SW-421 markers targeting R genes for tomato; (c) SCN131000 marker targeting R gene Tm22 for tomato mosaic disease; (d1-3) Pmi3, SCAR-1, and Rex-1 markers used to target 3 R genes of root knot nematode diseases in tomato; (e1-2) oomycete R gene screening using Ph3-2 and Ph3-3 markers; (f1-4) 8F/12R, 8F/10R, 10F/10R, and P7 markers linked to leaf mold disease; $\mathrm{R}$ and $\mathrm{S}$ constitute the representatives of resistance and susceptible allele, respectively; M indicates DL DNA marker; gene-based markers are represented in bold.

Fungi-high-efficiency markers for MAS in tomato

Thirteen potential markers associated with 6 fungus diseases were evaluated in order to determine those with high-efficiency in the process of fungus resistance screening for MAS programs. For leaf mold disease, $8 \mathrm{~F} / 12 \mathrm{R}, 8 \mathrm{~F} / 10 \mathrm{R}$, and $10 \mathrm{~F} / 10 \mathrm{R}$ markers were used to target Cf9 $\mathrm{R}$ gene while marker P7 related to Cf19 was exploited. Genetic bands generated from PCR based on these markers were credible, thus suggesting these markers to be efficient and designated as efficient markers. Interestingly, all 4 markers were developed using sequence of R gene-specific locus (Fig. 1f). Powdery mildew R gene screening was based on SCAB01 and SCAG11 markers linked to $\mathrm{Ol}-1$ gene, but only the result from 


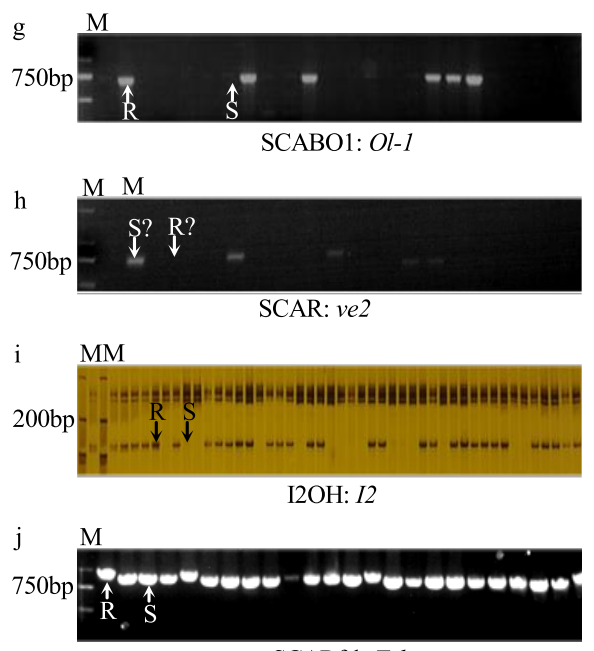

SCARfrl: $\mathrm{Frl}$
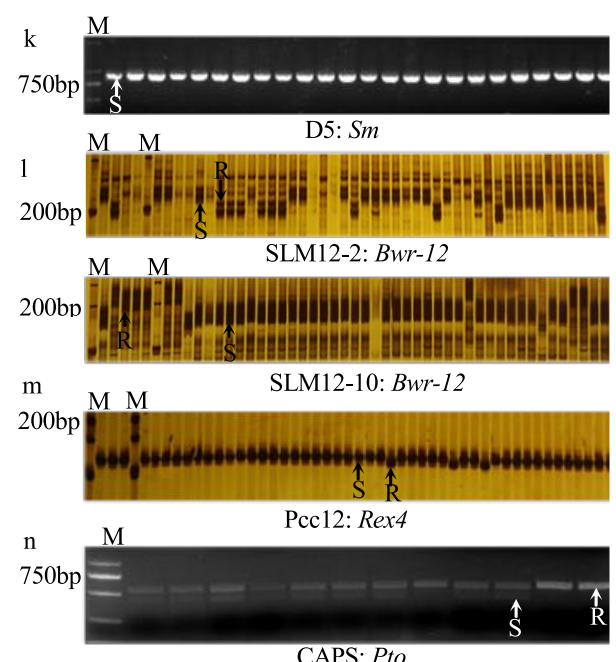

CAPS: Pto

Fig. 2 Gel pictures of screened tomato breeding lines using molecular markers related to major disease resistance genes (R genes). (g) SCAB01 marker targeting Ol-1 R gene for powdery mildew; (h) SCAR marker linked Ve2 gene for verticilium wilt screening; (i) I2OH marker related to fusarium wilt R gene; (j-k) SCARfrl and D5 markers for Fusarium crown, root rot and gray leaf spot disease; (l) SLM12-2 and SLM12-10 linked to Bwr-12 R gene against bacterial wilt; (m) pcc12 markers screening for bacterial spot; (n) CAPS marker linked to Pto R gene; R and S constitute the representatives of resistance and susceptible allele, respectively; M indicates DL DNA marker.

Table 2 Summary of markers considered as efficient markers for the selection of R-genes for major tomato fungi, bacteria, virus, and nematode diseases and their corresponding genes, alleles and sources.

\begin{tabular}{|c|c|c|c|c|c|c|c|}
\hline \multirow[t]{2}{*}{ Disease } & \multirow[t]{2}{*}{ R gene } & \multirow[t]{2}{*}{ Marker } & \multicolumn{3}{|c|}{ Reported allele size (bp) } & \multicolumn{2}{|c|}{ DNA sequencing } \\
\hline & & & $\mathrm{R}$ allele & S allele & Ref. & $\mathrm{R}$ allele & S allele \\
\hline \multirow[t]{6}{*}{ TYLCV } & Ty-1 & SCAR1 & 530 & 610 & {$[38]$} & $\checkmark$ & $\checkmark$ \\
\hline & Ty 1, Ty 3 & ACY & 132 & 123 & {$[16]$} & $\checkmark$ & $\checkmark$ \\
\hline & Ty 1, Ty 3 & Ty1-3 & 209 & 197 & [37] & $\checkmark$ & $\checkmark$ \\
\hline & Ty-3 & P6-25 & 660 & 320 & [39] & $\checkmark$ & $\checkmark$ \\
\hline & Ty-3a & P6-25 & 630 & 320 & & $\checkmark$ & $\checkmark$ \\
\hline & Ty- $3 b$ & P6-25 & 450 & 320 & & $\checkmark$ & $\checkmark$ \\
\hline \multirow[t]{2}{*}{ Late blight } & Ty-2 & SCAR2 & 900 & 800 & {$[38]$} & $\checkmark$ & $\checkmark$ \\
\hline & Ph3 & $\mathrm{Ph} 3-2$ & 149 & 131 & {$[36]$} & $\checkmark$ & $\checkmark$ \\
\hline TSWV & Ph3 & Ph3-3 & 120 & 130 & & $\checkmark$ & $\checkmark$ \\
\hline Fusarium wilt & $S w-5 b$ & Sw-5-2 & 574 & 510,464 & [19] & $\checkmark$ & $\checkmark$ \\
\hline \multirow[t]{4}{*}{ Leaf mold } & $I 2$ & $\mathrm{IO} 2 \mathrm{H}$ & $150-200$ & 0 & [27] & $\checkmark$ & $x$ \\
\hline & $C f 9$ & $8 \mathrm{~F} / 12 \mathrm{R}$ & 1500 & 1600 & [18] & $\checkmark$ & $x$ \\
\hline & $C f g$ & $8 \mathrm{~F} / 10 \mathrm{R}$ & 1400 & 1500 & & $\checkmark$ & $x$ \\
\hline & Cf9 & $10 \mathrm{~F} / 10 \mathrm{R}$ & 850 & 1200,1500 & & $\checkmark$ & $x$ \\
\hline \multirow[t]{2}{*}{ RKN } & Cf19 & P7 & 300 & 240 & [17] & $\checkmark$ & $\checkmark$ \\
\hline & Mi1-2 & PMi3 & 550 & 350 & {$[30]$} & $\checkmark$ & $\checkmark$ \\
\hline Bacterial spot & $M i-1.2$ & SCAR-1 & 380 & 430 & [29] & $\checkmark$ & $\checkmark$ \\
\hline ToMV & $\operatorname{Rex} 4$ & Pcc12 & 113 & 119 & {$[32]$} & $\checkmark$ & $\checkmark$ \\
\hline FCR & $\operatorname{Tm} 22$ & SCN131000 & 580,420 & $420,360,220$ & [23] & $\checkmark$ & $\checkmark$ \\
\hline TYLCV & $\mathrm{Frl}$ & SCARfrl & 1000 & 950 & [34] & $\checkmark$ & $\checkmark$ \\
\hline
\end{tabular}

TYLCV, tomato yellow leaf curl virus; TSWV, tomato spotted wilt virus; RKN, root knot nematode; ToMV, tobacco mosaic virus; FCR, Fusarium crown and root rot; bp, base pair. $\checkmark$ indicates successfully sequenced amplicons and $X$ indicates not sequenced. 
SCAB01 was acceptable (Fig. 2g). Verticilium wilt screening was with two SCAR markers respectively linked to resistance genes $V e 1$ and $V e 2$. After data analysis, Ve1-associated SCAR marker was immediately discarded due to the absence of amplified genetic bands, and at the same time the genetic bands amplified using the Ve2-linked SCAR marker were completely different from the reference data (Fig. 2h). This is the main reason why SCAR marker linked to Ve1 and Ve2 genes were not ranked in the group of efficient markers. Screening of resistance to fusarium wilt was evaluated using three different markers At2, I2OH, and P7-43DF1, which are related to three different strains of the pathogens namely $I 1, I 2$, and $I 3$. The $I 2$ gene-linked marker $\mathrm{I} 2 \mathrm{OH}$ yielded relatively clear and informative PCR products when compared to At2 and P7-43DF1 counterparts, thus placing $\mathrm{I} 2 \mathrm{OH}$ under the group of efficient marker (Fig. 2i). In the control of fusarium crown and root rot, $\mathrm{Frl}$ gene is targeted while for gray leaf spot, $\mathrm{Sm}$ gene is tracked. Both these R genes were evaluated using SCARfrl and D5 markers of which PCR amplicons expressed clear bands. Although D5 is a gene-based marker, no resistance allele was found during MAS assay, thus putting it out of the efficient marker group (Fig. 2jk).

\section{Bacteria-high-efficiency markers for MAS in tomato}

Three major bacterial diseases in tomato were investigated including bacterial wilt, bacterial spot and bacterial speck SLM12-2, SLM12-10, SLM617 markers linked to QTLs Bwr-12 and SLM6-138 linked to QTLs Bwr-6 were used in screening against bacterial wilt, while pcc12 and Pto markers were corresponding to R gene Rex4 and Pto in the control of bacterial spot and speck, respectively (Fig. $2 \mathrm{~m}$ ). Results revealed that only pcc12 marker generated impressive data based on the amplified genetic bands. Moreover, this marker is developed using the DNA sequence of the resistance gene Rex4 specific locus, thus depicting it as an efficient marker (Fig. 2m). The SLM6-17 and SLM6-138 markers in this piece of experiment failed to generate amplified genetic bands under varied imposed PCR conditions. Furthermore, the amplicons obtained using SLM12-2, SLM12-10, and Pto did not fully correlate with the reference data and so they were not grouped with efficient markers. Considering all aspects, a total of 7 markers $(8 \mathrm{~F} / 12 \mathrm{R}, 8 \mathrm{~F} / 10 \mathrm{R}$, 10F/10R, P7, I2OH, SCARfrl, and pcc12) were classified as efficient markers in control of fungus and bacterial diseases in tomato lines (Table 2).
Table 3 Groups of breeding lines according to their incorporated number of $\mathrm{R}$ genes.

\begin{tabular}{ccc}
\hline No. of R gene & No. of breeding lines & Group \\
\hline 0 & 595 & I \\
1 & 197 & II \\
2 & 68 & III \\
3 & 41 & IV \\
4 & 22 & V \\
5 & 15 & VI \\
6 & 19 & VII \\
7 & 6 & VIII \\
8 & 1 & IX \\
\hline
\end{tabular}

The size and nucleotide sequence of amplicons using efficient markers were confirmed through DNA sequencing of their corresponding PCR products. Of the 20 effective markers selected, only SCN131000 marker is a CAPS marker that would require restriction of its genetic bands by an enzyme. Amplicon sizes of the successfully sequenced efficient markers corroborated the reference data. The specific location of gene-based markers was performed using the online bioinformatics NCBI Blast tool. (As example accessions of resistance genes ACY, 8F/10R, and Sw-5-2 are HG975445, AJ002236, and AY007366, respectively). In case of CAPS marker, DNA sequencing result showed one AccI restriction enzyme site (GTATAC) in resistance allele while for susceptible allele two restriction sites were observed, which is consistent with electrophoresis results (Fig. 2n).

\section{Spectrum access and source of resistance among the breeding lines}

As much as commercial hybrids are carrying different $\mathrm{R}$ genes in type and in number, it is obvious that these $\mathrm{R}$ genes are being randomly distributed among their derivative breeding lines. In view of tracking $\mathrm{R}$ genes in breeding lines, 36 molecular markers were used, and among them, only the results obtained from 20 markers were informative and considered here. Grouping of breeding lines was established based on the number of $\mathrm{R}$ genes transported. A larger proportion 595 breeding lines were scored and placed under the group without resistance allele (group I). A total of 365 breeding lines carrying R genes encompassed groups II-IX as revealed by molecular markers (Table 3 ). In general, 36 markers related to $26 \mathrm{R}$ genes that control 14 diseases were disposed in upstream of this test, which represented an average of 1.38 markers per gene and 1.86 resistance genes per disease. In 
downstream of this assay, only 20 efficient markers targeting $18 \mathrm{R}$ genes responsible for the control of 12 diseases were recorded, thus corresponding to 1.11 markers per gene and $1.5 \mathrm{R}$ genes per disease.

\section{DISCUSSION}

\section{Selection of robust markers could enhance MAS process}

MAS is an indirect selection process where a trait of interest is selected based on a marker, which constitutes a breakthrough in resistance breeding of tomato. Many diseases that challenge tomato production are caused by agents such as virus, fungus, bacteria, nematode, and oomycete. Progress has been made to identify followed by introgression of resistance genes to these pathogens into tomato cultivars with the aid of molecular markers as tags. Therefore, robustness and reproducibility of a given marker is a prerequisite for its application in MAS. Here, we validate 36 molecular markers that target 26 resistance genes, known for regulating fourteen important tomato diseases. To optimize and accelerate MAS process in this work, all markers are validated under a properly controlled PCR reaction. In case of control against TYLCV, three $\mathrm{R}$ genes Ty1, Ty2, and Ty 3 have been commercially used worldwide so that many tomato breeding programs have oriented their breeding objectives towards incorporation of these genes into susceptible varieties. A total of 8 markers are exploited and among them, 6 (ACY, Ty1-3, P6-25, SCAR1, SCAR2, P116) were selected as efficient markers. Though marker P6-25 shows outstanding performance, it could generate recombination events during MAS as observed by Adedze et al [14] when comparing efficiency of ACY to P6-25. Hereof, ACY and Ty13 known as gene-based markers are more preferable and recommended to tract Ty 1 and/or Ty 3 in tomato. However, P6-25 could be specifically used to explore Ty 3 resistance gene and its derivative alleles Ty3, Ty $3 a$, and Ty3b. ACY and Ty1-3 are developed based on gene locus Solyc06g051170 and Solyc06g051190, respectively $[14,15]$. For Ty1 tracking, SCAR1 has emerged as a promising marker, while SCAR2 and P1-16 could be effectively used for Ty2 detection. Until now, no gene locus specific marker is developed for Ty 2 in tomato due to severe recombination suppression in Ty2 mapping region, which impedes its cloning [18]. Regarding tomato spotted wilt virus and tobacco mosaic virus, Sw-5-2 and SCN131000 markers are respectively regarded as efficient markers for re- sistance screening. The SCN131000 is a CAPS marker tightly linked to Tm22 gene while Sw-52 is a locus specific marker developed using $S w-5$ gene sequence (accession AY007366) [17]. With regard to leaf mold resistance screening, 4 genebased markers are selected due to their robustness. 8F/12R, 8F/10R, 10F/10R Markers are developed using DNA sequence of the resistance gene $C f-9$ (accession number: AJ002236), while P7 is designed based on Solyc01g006550 locus of Cf19 gene [18, 19]. Based on previously described, all 4 gene-based markers are co-dominant markers. Unexpectedly, $8 \mathrm{~F} / 10 \mathrm{R}$ marker in this study behaved as a dominant marker; this may be attributed to the imposed PCR reaction conditions. I2OH and SCARfr1 Markers appear with confidence in screening of tomato lines against fusarium wilt and fusarium crown and root rot. Indeed, these two markers also display accurate amplifications under the current experimental conditions. The most devastating tomato bacterial diseases include bacterial wilt, bacterial spot and bacterial speck [20]. A total of 5 markers are involved in screening against bacterial wilt and bacterial speck. Unfortunately, none of these markers shows accurate PCR amplicons, which may be due to their low reproducibility. Screening against bacterial spot has exhibited pcc12 marker is robust to explore Rex4 resistance gene. This gene is currently finemapped [21], which could accelerate its cloning and lead to the development of a gene-based marker since Pcc12 is a Rex4-linked marker. In screening against nematode and oomycete, root knot nematode and late blight are two most important diseases surveyed. In the former, Mi-1-linked marker Rex-1, Mi1-2-linked marker Pmi3 and Mi-1.2 gene-based marker SCAR-1 are identified as efficient markers whereas in the latter, Ph3-linked markers Ph3-2 and Ph3-3 are promoted as high-efficiency markers. In summary, 20 molecular markers are recommended for targeting $18 \mathrm{R}$ genes in control of $12 \mathrm{ma}-$ jor diseases in tomato caused by fungus, bacteria, virus, nematode, and oomycete. Two main reasons could explain the desertion of certain markers in this work. Firstly, of the 14 diseases investigated, two resistance alleles including verticilium (Ve1 and $\mathrm{Ve} 2$ ) and gray leaf spot $(\mathrm{Sm})$ were not detected. Secondly, diseases such as tobacco mosaic virus, powdery mildew, bacterial wilt, fusarium wilt and tomato yellow leaf curl disease lacked resistance gene of some strains in breeding lines (Tm1, Bwr$6, I 1, I 3, T y 4$ and ty5). Thirdly, certain markers are weakly expressed and others generated discordant genetic bands as compared to the inference data. In 
each of these 3 cases, the $\mathrm{R}$ gene and its associated molecular marker were excluded, which is probably due to their low reproducibility under the imposed PCR reaction condition. Not all developed markers have the same reproducibility, thus arguing the concept of several different marker development for a single gene. Adedze et al [14] has reported that it may not be advisable to depend solely on a single type of molecular marker for MAS because it may not always generate accurate band pattern under different experimental conditions. So far, some of the gene-linked markers could be easily improved as locus-specific marker following the cloning of their related $\mathrm{R}$ gene, except $\mathrm{Ty} 2$ that may require complex cloning technique. Here, we recommend the selected effective markers as well as the controlled PCR reaction condition as a diagnostic kit for tracking $\mathrm{R}$ genes controlling 12 tomato diseases.

\section{Potential sources of resistance for genetic improvement in tomato}

Lack of attention and sources of resistance to some diseases is reported as principal factors that affect breeding for resistance in China [20]. This work has once again attempted to draw our attention to the most devastating diseases of the China's tomato industry. Identification of new sources of resistance could greatly contribute to resistance breeding in future. Actually, several breeding lines are developed by breeders in public and/or private sectors. However, most of these lines are left in stock and only few are routinely implicated in breeding program. Moreover, selection of these few lines is often empirically executed on the field, meaning that those lines that are resistant to undetected disease or under quarantine restriction could not be accessed. Knowledge of different genetic backgrounds such as breeding lines or germplasms carrying different types of $\mathrm{R}$ genes is essential to provide the tomato breeding program with genetically diverse sources of resistance. Marker assisted selection is a selection tool widely used in the identification of the $\mathrm{R}$ gene. Its importance and the need for its involvement in the DHS test in the future are mentioned [13]. Based on MAS with the help of the R gene-associated markers, we have detected different sources of resistance against several diseases among the 964 breeding lines stored in Green Port company. The breeding lines are grouped based on the number of $\mathrm{R}$ genes incorporated as revealed by molecular markers. Comprehensively, $62 \%$ of the lines are deprived of R gene while $38 \%$ carry R genes against 12 diseases of tomato. These $62 \%$ of lines could be stocked for other breeding purpose or used as susceptible control varieties during resistance breeding. The remaining $38 \%$ of lines could constitute sources of resistance against these 12 tomato diseases in some tomato growing areas of high vulnerability. In conclusion, this work elucidates efficient markers with high-accuracy and reproducibility, as well as different sources of resistance for promoting resistance breeding in tomato.

Marker technology is importantly used in the implementation of MAS and gene pyramiding in vegetable crops. Nowadays, numerous molecular markers have been successfully developed and extensively used in tomato breeding program. Notwithstanding, the accuracy and reproducibility of some of them are still affected following a slight modification of their previous PCR reaction condition. With the vision to optimize MAS processing at Green Port Company, the same PCR reaction conditions were imposed to all molecular markers evaluated. From our findings, 20 efficient markers were pointed out for targeting $18 \mathrm{R}$ genes and were selected as robust markers in screening against 12 tomato diseases. Meanwhile, these markers allow us to access potential resistance sources among our breeding lines. We thus recommend these markers to plant scientists, agronomists, breeders and other seed companies, while shedding light on the R gene pool stored in our company, which could be involved in a breeding program in the nearest future. Growing area of tomato is gradually expanding, but due to the relatively warmer and more humid condition of greenhouse cultivation, tomato is easily infected by many pathogens, thus compromising yield per hectare. To efficiently control those diseases, we recommend high-efficiency combination of their corresponding $\mathrm{R}$ genes while suggesting their pyramiding into commercial tomato varieties as a pragmatic breeding approach.

Acknowledgements: We are grateful to the leaders of Jiangsu province and Suqian city in China. This work is fully supported by two talent projects: 2017 Jiangsu Province Entrepreneurial Innovation Talent Program and 2017 Suqian City Entrepreneurial Innovation Leading Talent Program.

\section{REFERENCES}

1. Huo JY (2016) The current status of tomato industry in China and its safety precautions Vegetables 6, 1-4.

2. Ma ZH (2017) The change trend of tomato varieties in China based on the demand of production market. China Veg 3, 1-5. 
3. Jones JB, Zitter TA, Momol TM, Miller SA (2014) Compendium of Tomato Diseases and Pests, 2nd edn, APS Press, Minnesota, USA.

4. Gao YM, Hu JK, Zhao TT, Li JF (2017) The progress of studies on Mi-1 gene with resistance to root-knot nematode in tomato (Solanum lycopersicum). Mol Plant Breed 15, 3010-3015.

5. Yan Z, Pérez-de-Castro A, Díez MJ, Hutton SF, Visser RGF, Wolters MA, Bai Y, Li J (2018) Resistance to tomato yellow leaf curl virus in tomato germplasm. Front Plant Sci 9, ID 1198.

6. Van Ooijen G, van den Brug HA, Cornelissen BLC, Takken F (2007) Structure and function of resistance proteins in solanaceous plants. Ann Rev Phytopathol $45,43-72$.

7. Lee JM, Oh CS, Yeam I (2015) Molecular markers for selecting diverse disease resistances in tomato breeding programs. Plant Breed Biotech 3, 308-322.

8. Hanson P, Lua SF, Wanga JF, et al (2016) Conventional and molecular marker-assisted selection andpyramiding of genes for multiple disease resistance in tomato. Scientia Hort 201, 346-354.

9. Prasanna HC, Sinha DP, Rai GK, Krishna R, Kashyap SP, Singh NK, Singh M, Malathi VG (2015) Pyramiding Ty-2 and Ty-3 genes for resistance tomonopartitie and bipartite tomato leaf curl viruses in India. Plant Pathol 64, 256-264.

10. Poczai P, Varga I, Laos M, et al (2013) Advances in plant gene targeted and functional markers: a review. Plant Methods 9, ID 6.

11. Arens P, Mansilla C, Deinum D, et al (2010) Development and evaluation of robust molecular markers linked to disease resistance in tomato for distinctness, uniformity and stability testing. Theor Appl Genet 120, 655-664.

12. Neik TX, Barbetti MJ, Batley J (2017) Current status and challenges in identifying disease resistance genes in Brassica napus. Front Plant Sci 8, ID 1788.

13. Pilet-Nayel ML, Moury B, Caffier V, Montarry J, Kerlan MC, Fournet S, Durel CE, Delourme R (2017) Quantitative resistance to plant pathogens in pyramiding strategies for durable crop protection. Front Plant Sci 8, ID 1838.

14. Adedze YMN, Lu X, Chofong GN, et al (2018) Development of a new molecular marker for the resistance to tomato yellow leaf curl virus. Biomed Res Int 2018, ID 8120281.

15. Zhao TT, Jiang Jb, Liu G, He SS, Zhang H, Chen XL, Li JF, Xu XY (2016) Mapping and candidate gene screening of tomato Cladosporium fulvum-resistant gene Cf-19, based on high-throughput sequencing technology. BMC Plant Biology 16, ID 51.

16. Truong HTH, Choi HS, Cheou MC, Lee HE, Kim JH (2011) Use of Cf-9 Gene-based markers in markerassisted selection to screen tomato cultivars with resistance to Cladosporium fulvum. Hort Environ Biotechnol 52, ID 204.
17. Dianese EC, De Fonseca MEN, Goldbach R, Kormelink R, Inoue-Nagata AK, Resende RO, Boiteux LS (2010) Development of a locus-specific, co-dominant SCAR marker for assisted-selection of the $S w-5$ (Tospovirus resistance) gene cluster in a wide range of tomato accessions. Mol Breed 25, ID 143.

18. Julio G, Sanabria D, Veramendi S, Plata G, Angulo A, Crespo M (2013) Resistencia genética de híbridos de tomate (Solanum lycopersicum. (mill.) al virus del bronceado (TSWV). Agronomía Costarricense 37, 61-69.

19. Huang CC, Cui YY, Weng CR, Zabel P, Lindhout P (2000) Development of diagnostic PCR markers closely linked to the tomato powdery mildew resistance gene Ol-1 On chromosome 6 of tomato. Theor Appl Genet 101, 918-924.

20. Ishibashi K, Masuda K, Naito S, Meshi T, Ishikawa M (2007) An inhibitor of viral RNA replication is encoded by a plant resistance gene. Proc Natl Acad Sci USA 104, 13833-13838.

21. Sobir, Ohmori, Murata M, Motoyoshi F (2000) Molecular characterization of the SCAR markers tightly linked to the Tm-2 locus of the genus Lycopersicon. Theo Appl Genet 101, 64-69.

22. Hanson, Peter, Chee-Wee, Tan, Fang-I H, Shu-Fen L, Ledesma D, Jaw-Fen W (2013) Evaluation of near isogenic tomato lines with and without the bacterial wilt resistance allele, Bwr-12. Tomato Genet Co-op Rep 63, 15-21.

23. Wang JF, Ho F, Truong HTH, Huang SM, Balatero $\mathrm{CH}$, Dittapongpitch V, Hidayati N (2013) Identification of major QTLs associated with stable resistance of tomato cultivar Hawaii 7996 to Ralstonia solanacearum. Euphytica 190, 241-252.

24. Kawchuk LM, Hachey J, Lynch DR, et al (2001) Tomato Ve disease resistance genes encode cell surface-like receptors. Proc Natl Acad Sci USA 98, 6511-6515.

25. Popoola AR, Ercolano MR, Feriello F, et al (2014) CAPS markers TAO1 and TG105 in the identification of 2 resistant gene in Nigerian accessions of tomato, Solanum lycopersicum L. Niger J Biotech 28, 43-51.

26. Barillas AC, Mejia L, Sanchez-Perez A, Maxwwell DP (2008) CAPS and SCAR markers for detection of I-3 gene introgression for resistance to Fusarium oxysporum f. sp. lycopersici race 3. Rep Tomato Genet Coop 58, 11-17.

27. Seah S, Williamson VM, Garcia BE, Mejía L, Salus MS, Martin CT, Maxwell DP (2007) Evaluation of a co-dominant SCAR marker for detection of the Mi-1 locus for resistance to root-knot nematode in tomato germplasm. Tomato Genet Coop 57, 37-40.

28. El Mehrach K, Mejía L, Gharsallah-Couchane S, et al (2005) PCR-based methods for tagging the Mi-1 locus for resistance to root-knot nematode in begomovirus-resistant tomato germplasm. Acta Hortic 695, 263-270. 
29. Williamson VM, Ho JY, Wu FF, Miller N, Kaloshia I (1994) A PCR-based marker tightly linked to the nematode resistance gene, $\mathrm{Mi}$, in tomato. Theor Appl Genet 87, 757-763.

30. Pei C, Wang H, Zhang J, Wang Y, Francis DM, Yang $\mathrm{W}$ (2012) Fine mapping and analysis of a candidate gene in tomato accession PI128216 conferring hypersensitive resistance to bacterial spot race T3. Theor Appl Genet 124, 533-542.

31. Yang WC, Francis DM (2005) Marker-assisted selection for combining resistance to bacterial spot and bacterial speck in tomato. J Amer Soc Hort Sci 130, 716-721.

32. Mutlu N, Demirelli A, Ilbi H, Ikten C (2015) Development of co-dominant SCAR markers linked to resistant gene against the Fusarium oxysporum f. sp. radicis-lycopersici. Theor Appl Genet 128, 1791-1798.

33. Yang HH, Zhao TT, Jiang JB, Wang SB, Wang AX, Li JF, Xu XY (2017) Mapping and screening of the tomato Stemphylium lycopersici resistance gene, Sm, based on bulked segregant analysis in combination with genome re-sequencing. BMC Plant Biol 17, ID 266.

34. Reza S, Hutton SF, Scott JW (2015) Designing new
DNA markers and determining the effective size of $P h-2$ and $P h-3$ introgressions for late blight resistance stacking purposes in tomato. Tomato Genet Co-op Rep 65, 22-31.

35. Hu X, Wang R, Li FF, Zhou T, Yang WC (2014) Development of new marker for tomato TYLCV resistant gene and its application in selection of multi resistant gene pyramiding. China Veg 10, 18-23.

36. Yang XH, Caro M, Hutton SF, et al (2014) Fine mapping of the tomato yellow leaf curl virus resistance gene Ty-2 on chromosome 11 of tomato. Mol Breed 34, 749-760.

37. Ji Y, Salus MS, van Betteray, et al (2007) Codominant SCAR markers for detection of the Ty-3 and Ty-3a loci from Solanum chilense at $25 \mathrm{cM}$ of chromosome 6 of tomato. Genet Co-op Rep 57, 25-28.

38. Fu W, Xin XR, Jin Y, Wang HX (2013) Identification of Ty-1, Ty-2 and Ty-3 genes of tomato (Lycopersicon esculentum) by multiplex PCR. Chi Hort 2013, ID 04.

39. Yang HH, Xu XY, Jiang JB, Li JF (2016) Advanced progress on tomato yellow leaf curl disease resistance genes and disease resistance breeding. Mol Plant Breed 14, 2044-2049. 